\title{
Effects of preferred prey density and temperature on feeding success and recent growth in larval mackerel of the southern Gulf of St. Lawrence
}

\author{
Dominique Robert ${ }^{1,3, *}$, Martin Castonguay ${ }^{2}$, Louis Fortier ${ }^{1}$ \\ ${ }^{1}$ Québec-Océan, Département de Biologie, 1045 avenue de la Médecine, Université Laval, Québec, Québec G1V 0A6, Canada \\ ${ }^{2}$ Institut Maurice-Lamontagne, Ministère des Pêches et des Océans, CP 1000, Mont-Joli, Québec G5H 3Z4, Canada \\ ${ }^{3}$ Present address: Fisheries Research Station, Kyoto University, Nagahama, Maizuru, Kyoto-fu 625-0086, Japan
}

\begin{abstract}
We evaluated the effects of preferred prey density and temperature on the feeding success and recent growth of Atlantic mackerel larvae from 4 consecutive annual cohorts (1997 to 2000) in the southern Gulf of St. Lawrence. Individual feeding success (residuals of the linear regression of preferred prey carbon in the gut content on larval length) and recent growth (average width of last 3 otolith increments) were determined for a stratified subsample of larvae in each year and among different length classes. The density of preferred prey best explained variations in feeding success and growth in first-feeding larvae $(<7 \mathrm{~mm})$, while temperature was the main source of growth variability during older larval stages. The feeding success and growth of early larvae increased with the density of Pseudocalanus sp. nauplii until a similar satiation threshold of $1 \mu \mathrm{gC} \mathrm{l}^{-1}$. Recent growth increased linearly with temperature during the late larval stage, without any indication of a temperature optimum. These results suggest that high abundance of the preferred prey at the onset of exogenous feeding and relatively warm temperature during the larval growth season are important prerequisites for the emergence of a strong year class in Atlantic mackerel.
\end{abstract}

KEY WORDS: Fish larvae · Prey availability · Temperature · Feeding success · Recent growth • Otolith microstructure $\cdot$ Atlantic mackerel $\cdot$ Scomber scombrus

Resale or republication not permitted without written consent of the publisher

\section{INTRODUCTION}

The recruitment of marine fish fluctuates widely from year to year, reflecting interannual differences in survival through the first year of life (e.g. Cushing 1990, Bradford 1992). Suboptimal growth during the larval stage is considered one of the main causes of recruitment failure (Houde 1987, 2008). Slow growth lowers the chances of survival of a given individual by increasing its vulnerability to predation (e.g. Chambers \& Leggett 1987, Miller et al. 1988, Takasuka et al. 2003). Any factor modifying the average growth rate of a larval cohort is expected to generate recruitment variability, as proposed in the growth-mortality conceptual framework (Anderson 1988). When suboptimal, biotic (e.g. prey type, availability and vulnerability) and abiotic (e.g. temperature) factors are expected to reduce larval growth as a consequence of a net decrease in feeding success, or a reduction in the energy allocated to growth even if food intake remains constant (Jobling 1997, Buckley et al. 2006).

Several field studies have identified environmental factors that impact larval feeding success or growth as potential predictors of recruitment (e.g. Dower et al. 2002, Baumann et al. 2006, Buckley \& Durbin 2006). However, predictive correlations linking year-class strength to environmental conditions during early life remain scarce (Ottersen \& Loeng 2000, Platt et al. 2003, Takasuka et al. 2007). Prey availability and temperature are generally considered the most important sources of variability in feeding success and growth (Dower et al. 2002, Takahashi \& Watanabe 2005, Takasuka \& Aoki 2006), although factors such as turbulence (Dower et al. 1997), and light availability (Fortier et al. 
1996, Buckley et al. 2006) may also play a role in their regulation. Feeding and growth are expected to increase exponentially at a decreasing rate with prey density until a satiation asymptote is reached (e.g. Ellertsen et al. 1989, Fortier et al. 1996, Buckley \& Durbin 2006). Feeding and growth increase linearly with temperature (Michaud et al. 1996, Dower et al. 2002, Baumann et al. 2006) or as a dome-shaped function if the optimal temperature is exceeded (Baumann et al. 2003, Buckley et al. 2004, Takasuka et al. 2007).

In a previous study (Robert et al. 2007) we compared the larval growth in 4 year classes of Atlantic mackerel Scomber scombrus in the southern Gulf of St. Lawrence, which comprised 1 year of exceptionally high recruitment (1999) and 3 years of low recruitment (1997, 1998, 2000). We concluded that the strong 1999 year class resulted from the combination of fast larval growth and low predation pressure (as indicated by weak selection for fast growth). On the Magdalen Shallows, larval mackerel strongly select Pseudocalanus sp. nauplii at first feeding $(<7 \mathrm{~mm})$ whereas larvae $\geq 7 \mathrm{~mm}$ select cladocerans and fish larvae (including their siblings), and these preferred prey represented an average of $66 \%$ of total carbon ingested among the 4 years (Robert et al. 2008). In the present study, we develop an index of feeding success based on the assumption that the preferred prey represents the easiest prey to capture-and hence the most profitable prey metabolically. We then explore the impact of preferred prey availability and temperature on the feeding success, early growth and, ultimately, recruitment of Atlantic mackerel.

\section{MATERIALS AND METHODS}

Sampling at sea. The Gulf of St. Lawrence is an inland sea connected to the Atlantic Ocean by the Belle-Isle and Cabot straits (Fig. 1a). Located in the southern part of the Gulf, the Magdalen Shallows form a discrete $50000 \mathrm{~km}^{2}$ bank characterized by relatively warm temperatures (up to $18^{\circ} \mathrm{C}$ ) and high zooplankton productivity during the summer period (de Lafontaine et al. 1991). These characteristics promote favorable conditions for the spawning and larval development of Atlantic mackerel.

Mackerel larvae 3 to $18 \mathrm{~mm}$ in standard length were captured from July to mid-August in 4 consecutive years (1997 to 2000) during $1 \mathrm{~d}$ surveys conducted on a weekly basis in the southeastern and northeastern areas of the Magdalen Islands (Fig. 1b). This sampling period covered both spawning and larval development seasons in all years. Sampling methods for mackerel larvae and zooplankton are detailed in Robert et al.
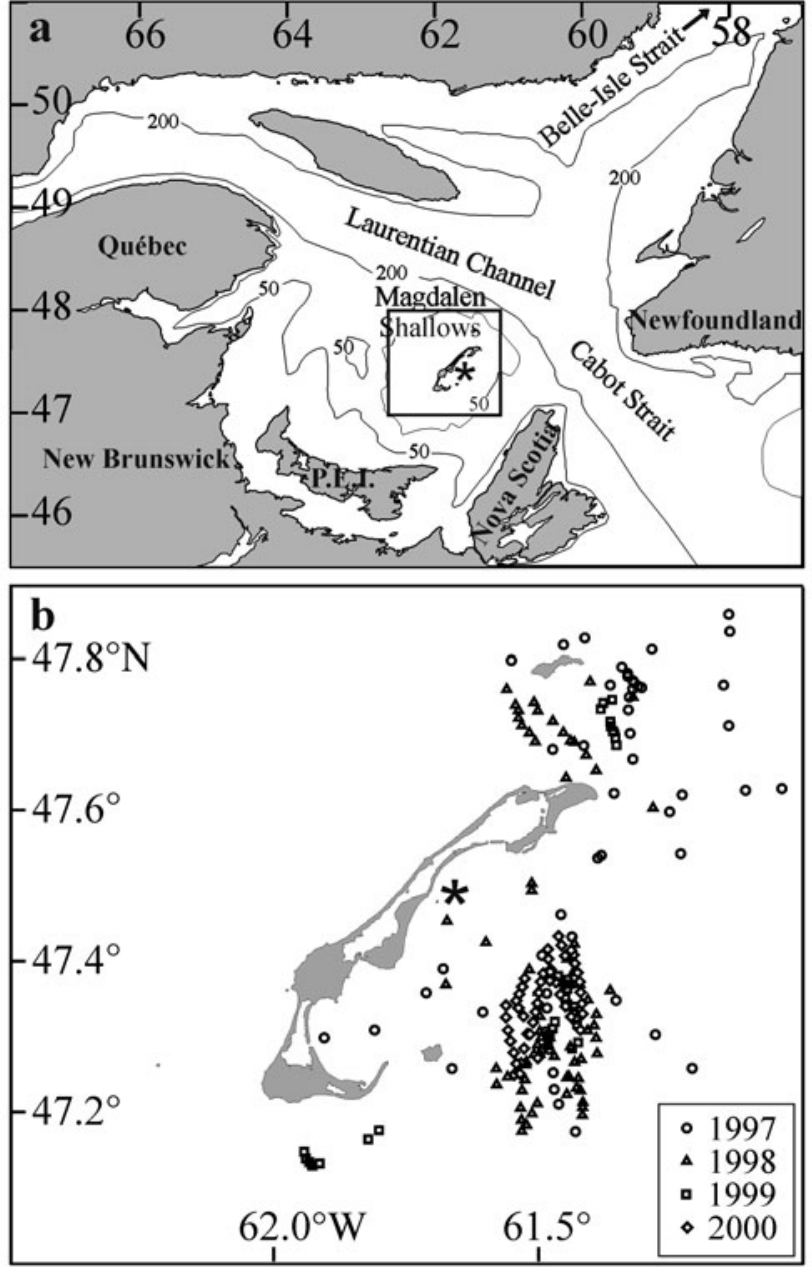

Fig. 1. (a) Gulf of St. Lawrence with isobaths in m. (b) Sampling area with the position of net tows where mackerel larvae were captured. * Location of the thermograph from which daily mean temperature data were obtained

(2007) and Robert et al. (2008), respectively. Briefly, the sampler consisted of a rectangular metal frame carrying 4 plankton nets deployed in a double-oblique tow pattern $\left(\sim 20 \mathrm{~min}\right.$ duration at $\left.\sim 1.3 \mathrm{~m} \mathrm{~s}^{-1}\right)$ : two $750 \mu \mathrm{m}$ mesh nets captured fish larvae, while two $64 \mu \mathrm{m}$ mesh cylindrical nets sampled their microzooplankton prey. The sampler was equipped with a Minilog probe (VEMCO) that recorded temperature and depth during deployment. Mackerel larvae were preserved in $95 \%$ ethanol for otolith analyses. Microzooplankton samples collected in the $64 \mu \mathrm{m}$ mesh nets were preserved in a $4 \%$ formalin seawater solution. Stratified subsamples of mackerel larvae were assembled for otolith and gut content analyses by randomly selecting individuals from predetermined length classes in each year (Table 1).

Feeding success index. The analysis of the gut content and prey field of Atlantic mackerel larvae is 
Table 1. Scomber scombrus. Number of larvae collected and used for stomach content and otolith analysis in each year

\begin{tabular}{|lccc|}
\hline Year class & $\begin{array}{c}\text { No. larvae } \\
\text { collected }\end{array}$ & $\begin{array}{c}\text { No. stomachs } \\
\text { examined }\end{array}$ & $\begin{array}{c}\text { No. otoliths } \\
\text { analyzed }\end{array}$ \\
\hline 1997 & 2371 & 99 & 338 \\
1998 & 15299 & 144 & 366 \\
1999 & 217 & 170 & 211 \\
2000 & 1401 & 143 & 343 \\
\hline
\end{tabular}

detailed in Robert et al. (2008). In summary, the digestive tract of mackerel larvae was dissected under a stereoscopic microscope and each prey was measured and identified to the lowest taxonomical level possible. The microzooplankton prey of larval Atlantic mackerel were enumerated in a known aliquot of the $64 \mu \mathrm{m}$ mesh nets and density values (number $\mathrm{l}^{-1}$ ) were transformed into carbon densities $\left(\mu \mathrm{gC} \mathrm{l}^{-1}\right)$ using specific length-weight relationships (Robert et al. 2008, their Table I). For Pseudocalanus sp. nauplii, mean size at a given developmental stage (NI to NVI) was used to estimate stage-specific carbon contents which were then summed across stages to obtain an estimate of total Pseudocalanus sp. nauplii carbon density ( $\mu \mathrm{gC}$ $\mathrm{l}^{-1}$ ). The densities of cladocerans and larval fish prey (the latter measured in the $750 \mu \mathrm{m}$ mesh nets) were transformed into carbon using the mean size of prey in the gut of mackerel larvae. Because zooplankton was enumerated in a random subset of samples only, some mackerel larvae from unanalyzed tows (11\% of total) could not be assigned a prey density and were excluded from further analysis.

We previously estimated selectivity of mackerel larvae for their prey (Robert et al. 2008) using Chesson's $\alpha$ index of prey electivity (Chesson 1978), which compares the relative abundance of a prey in the gut content of the predator and in the plankton. Briefly, Atlantic mackerel $<7 \mathrm{~mm}$ strongly selected for Pseudocalanus sp. nauplii, whereas mackerel $\geq 7 \mathrm{~mm}$ strongly selected for cladocerans and small fish larvae, and these preferred prey clearly dominated the diet of the 2 length classes (Robert et al. 2008). Assuming that the capture of these strongly selected prey provided mackerel larvae with the highest energy gain (energy gained minus energy expanded in capturing prey), feeding success is defined here as the ingested biomass of preferred prey expressed in carbon. Food intake as estimated from gut content varies with body size and time of day, 2 factors that may blur the statistical relationships linking feeding success to prey availability and temperature. In the present study, mackerel larvae were sampled from 15:00 to 23:00 h to cover their period of peak feeding (Fortier \& Villeneuve 1996). Within this time interval, gut content was not related to hour of capture. Therefore, we used the residuals of the linear regression of preferred prey intake (in carbon) on larval mackerel standard length as a length-independent index of feeding success.

Growth analysis. Daily growth was estimated from the width of otolith increments (Robert et al. 2007). Sagittal otoliths were mounted on slides using Crystalbound thermoplastic cement (Aremco Products), and polished with 30 and $3 \mu \mathrm{m}$ metallurgical lapping films when needed. Daily growth increments were measured and counted at $1000 \times$ magnification using a microscope connected to an Image-Pro Plus image analyzing system with a digital camera. Standard length (SL) and otolith radius (OR) were strongly and linearly correlated $\left(\mathrm{SL}=0.7725 \times \mathrm{OR}-0.5753, \mathrm{r}^{2}=0.91\right.$, $\mathrm{p}<0.0001, \mathrm{n}=1258$ ), and the slope of the regression did not change over the range of temperatures prevailing at capture (analysis of covariance [ANCOVA], p = 0.25 ; for larvae captured at temperatures of $<12,12$ to $<14,14$ to $<16$, and $\geq 16^{\circ} \mathrm{C}$ ). The stability of the relationship confirms the conclusion of Migoya (1989) that increment widths are a reliable estimate of the somatic growth of larval Atlantic mackerel under a wide range of temperatures.

Because growth and its variance tend to increase with age, a detrended growth index was computed (e.g. Baumann et al. 2003) to allow growth comparisons among larvae of different ages:

$$
D G_{i j}=\left(G_{i j}-G_{j}\right) S D_{j}^{-1}
$$

where $D G_{i j}$ is the detrended growth of individual $i$ at age $j_{\text {; }}$ and $G$ and $S D$ are the otolith growth (increment width) and standard deviation, respectively. This index provides a measure of growth performance independent of age and thus allows comparison among larvae of varying age.

Recent growth was defined as the average detrended growth achieved during the last 3 full d prior to capture (Dower et al. 2002). The edge of the otolith, representing the interruption of the last incomplete day of life, was not considered as a growth increment. The influence of prey availability and temperature on recent growth were assessed considering 4 distinct larval age categories ( 3 to 7,8 to 11,12 to 15 , and $>15$ d), corresponding to the standard length classes used to assess environmental influence on the feeding success and given by the regression AGE $=-10.24+11.34 \times \ln$ SL $\left(\mathrm{r}^{2}=0.80, \mathrm{p}<0.0001\right)$.

Statistical analysis. In the laboratory, fish food intake and gut content increase with prey availability until some satiation level is reached (e.g. Ivlev 1961, Houde \& Schekter 1980). This response is adequately described by an exponential rise-to-maximum function, which was fitted to the regression of feeding success (FS) on preferred prey density (PD): 


$$
F S=\mathrm{a}\left(1-\mathrm{e}^{-\mathrm{b} \cdot P D}\right)
$$

Feeding success is also predicted to be a linear or dome-shaped quadratic function of temperature (e.g. Jobling 1997). Since gut content reflects the food ingested during the last $\sim 4 \mathrm{~h}$ of life (Lough \& Mountain 1996, Llopiz \& Cowen 2008), the temperature recorded by the Minilog probe fitted on the sampler was considered representative of the conditions dictating feeding success at the time of capture and used in the analysis. Growth over the last $3 \mathrm{~d}$ more likely responds to longer-term fluctuations in temperature. Accordingly, recent growth was regressed against the daily average temperature recorded by a thermograph operated by the Department of Fisheries and Oceans Canada (DFO) at a depth of $10 \mathrm{~m}$ in the sampling area (Fig. 1).

\section{RESULTS}

\section{Seasonal and interannual fluctuations in temperature}

Daily average temperature recorded by the DFO thermograph increased irregularly from $11-13^{\circ} \mathrm{C}$ in late June to $13-18^{\circ} \mathrm{C}$ in mid-August during the years 1997 to 2000 (Fig. 2). Among the 4 years considered, 1999 was the warmest with an average of $14.1^{\circ} \mathrm{C} .1998$ and 2000 were about $1^{\circ} \mathrm{C}$ colder with 13.1 and $13.2^{\circ} \mathrm{C}$ means, respectively. Finally, 1997 was relatively cold with temperatures averaging $12.0^{\circ} \mathrm{C}$ during the growth season of Atlantic mackerel larvae.

\section{Seasonal and interannual fluctuations in the availability of preferred prey}

The abundance of Pseudocalanus sp. nauplii (mainly $P$. elongatus), the main prey of Atlantic mackerel lar-

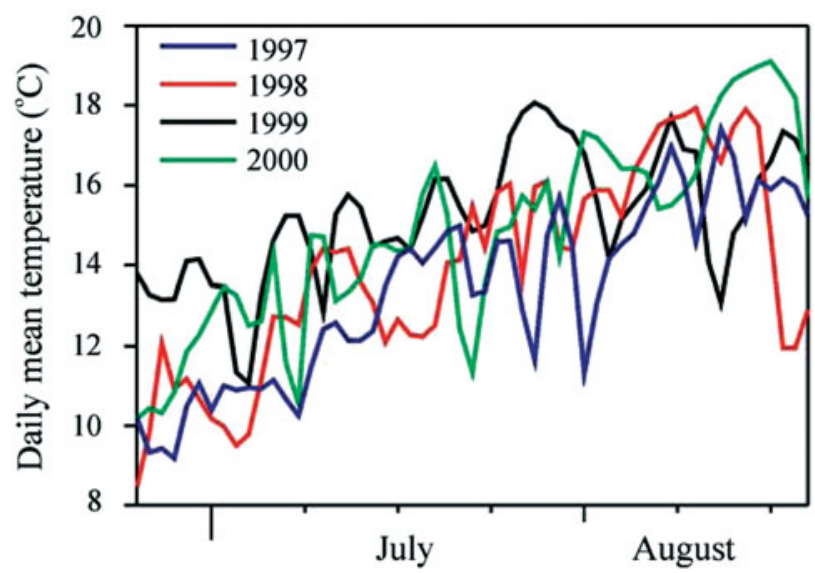

Fig. 2. Daily mean temperature time series recorded by the thermograph in the sampling area vae $<7 \mathrm{~mm}$, varied widely among years, with lowest $\left(0.3 \mu g \mathrm{C}^{-1}\right)$ and highest $\left(15.0 \mu \mathrm{gC} \mathrm{l}^{-1}\right)$ densities observed in August of 1999 and 2000 respectively (Fig. 3). Peak abundance occurred at variable times among years, from early July $(1998,1999)$ to midAugust $(1997,2000)$. The abundance of cladocerans (Evadne sp. and Podon sp.) and fish larvae, the main prey during the late larval stage, followed a different pattern within and among years (Fig. 3). Cladoceran density remained relatively constant throughout the 4 years, decreasing slightly in August. The density of the larval fish prey of mackerel larvae was relatively low throughout the season in 1997 and 1999. Despite high densities recorded in July of 1998 and 2000, the abundance of small fish larvae systematically reached low levels in August. The density of the 3 preferred prey

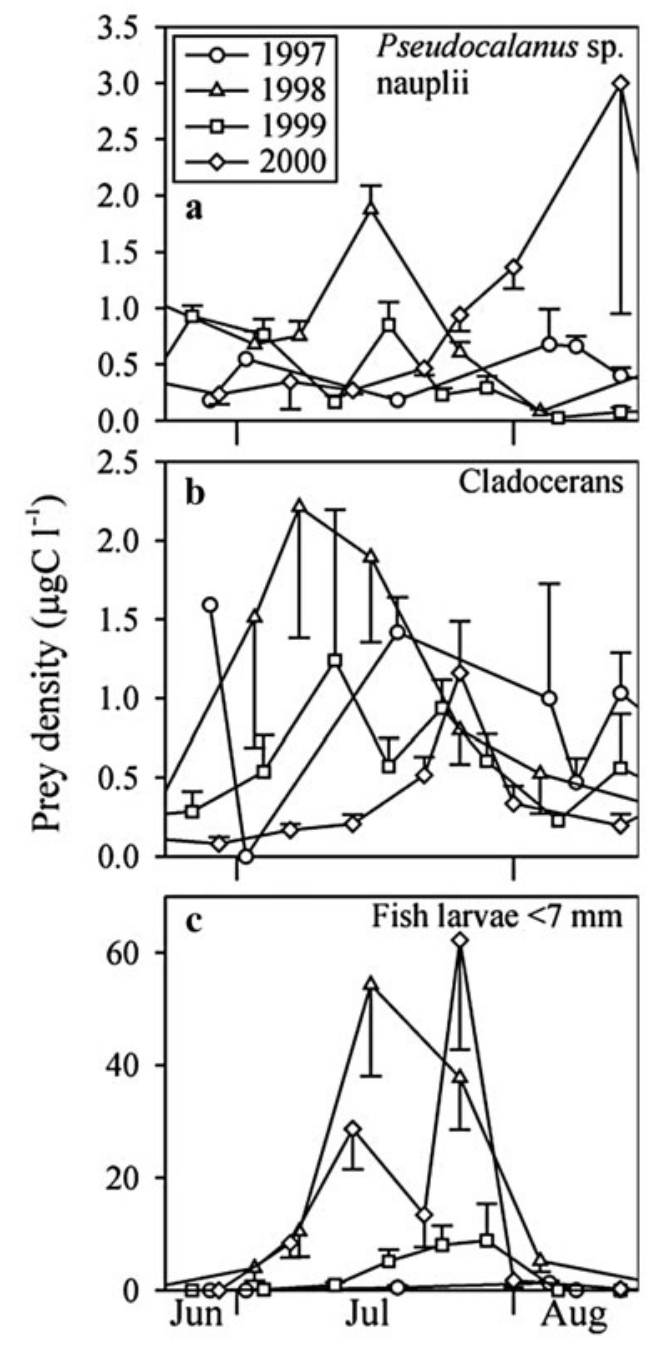

Fig. 3. Seasonal pattern in the density of (a) Pseudocalanus sp. nauplii, (b) cladocerans and (c) fish larvae during the larval mackerel growth season. Error bars represent the SE among samples corresponding to a given $1 \mathrm{~d}$ survey 


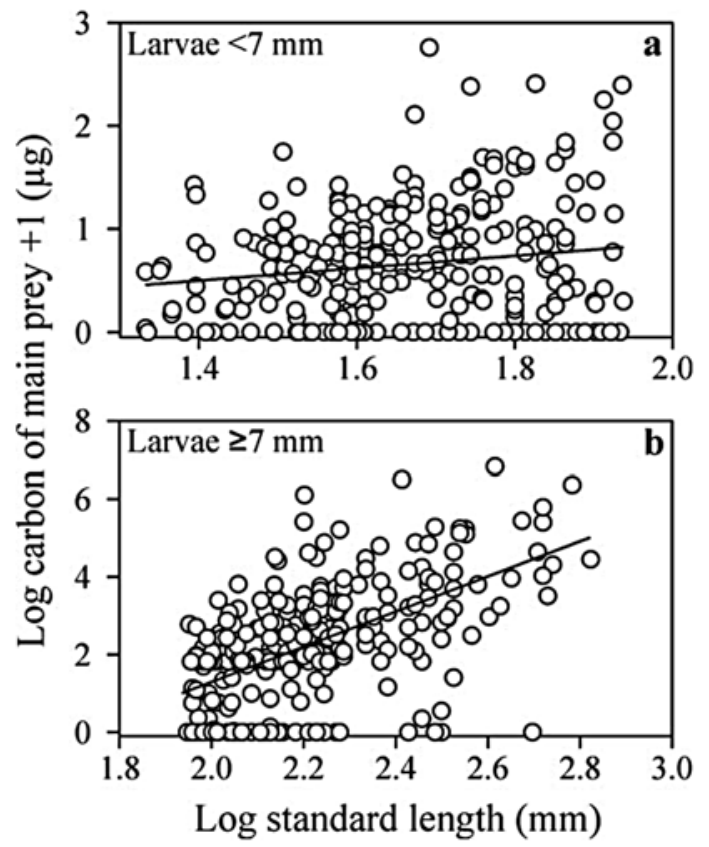

Fig. 4. Scomber scombrus. Carbon of preferred prey ingested in relation to standard length (SL) for larvae (a) $<7 \mathrm{~mm}$ and (b) $\geq 7 \mathrm{~mm}$. Preferred prey are (a) Pseudocalanus sp. nauplii and (b) cladocerans and fish larvae $<7 \mathrm{~mm}$. Data were log-transformed to reach normality of residuals. Equation of the linear regression is (a) $\mathrm{C}=0.601 \times \mathrm{SL}-0.342\left(\mathrm{r}^{2}=0.03, \mathrm{p}=0.01, \mathrm{n}=\right.$ 269); (b) $\mathrm{C}=4.525 \times \mathrm{SL}-7.757\left(\mathrm{r}^{2}=0.33, \mathrm{p}<0.01, \mathrm{n}=276\right)$

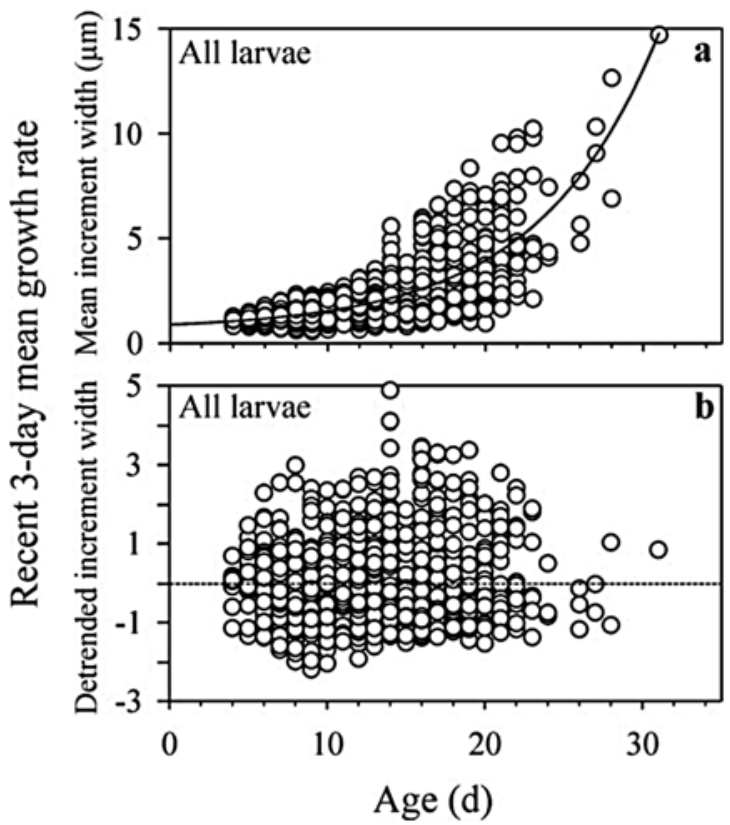

Fig. 5. Scomber scombrus. Recent 3 d mean growth rate achieved by larvae as a function of age. Growth is represented in (a) mean increment width and (b) mean detrended increment width. Equation of the exponential regression: increment width $=0.651+0.178 \times \mathrm{e}^{0.141 \mathrm{~A}}\left(\mathrm{r}^{2}=0.56, \mathrm{p}<0.0001, \mathrm{n}=1252\right)$. No significant relationship was found between detrended increment width and age $\left(\mathrm{r}^{2}=0.003, \mathrm{p}=0.06, \mathrm{n}=1252\right)$ taxa was not significantly correlated to temperature recorded during sampling or to daily mean temperature recorded by the thermograph (quadratic regression analyses, $\mathrm{p}>0.05$ ).

The carbon content of preferred prey increased linearly with mackerel standard length both in larvae $<7 \mathrm{~mm}$ that foraged on Pseudocalanus sp. nauplii and in larvae $\geq 7 \mathrm{~mm}$ that relied on cladocerans and fish larvae (Fig. 4). The data were log-transformed to normalize the residuals used as a length-independent index of feeding success.

\section{Recent growth in relation to age}

Mean otolith increment width over the last $3 \mathrm{~d}$ of life increased exponentially with larval mackerel age (Fig. 5a). Variance in recent growth also tended to increase with age. The detrended growth index used in correlations with prey availability and temperature was independent of age (Fig. 5b).

\section{Feeding success and recent growth in relation to preferred prey density}

No statistically significant relationship was found between the overall carbon in the gut (all prey) and the overall density of microzooplankton prey in situ (data not shown). A satiation function best explained the relationship between feeding success and the density of preferred prey available to mackerel larvae in the 3 to $<5 \mathrm{~mm}$ and 5 to $<7 \mathrm{~mm}$ length classes (Fig. 6a,b). In both length categories, feeding success increased exponentially at a decreasing rate until reaching a satiation threshold around $1 \mu \mathrm{gC}^{-1}$ of Pseudocalanus sp. nauplii. No effect of preferred prey density was observed on the feeding success of larger larvae (Fig. 6c,d).

In first-feeding larvae aged 3 to $7 \mathrm{~d}$, growth also reached an asymptote at a Pseudocalanus sp. nauplii density of about $1 \mu \mathrm{gC} \mathrm{l}^{-1}$ (Fig. 6e). Growth of larvae $>7 \mathrm{~d}$ was not related to the availability of preferred prey (Fig. 6f-h). The density of Pseudocalanus sp. nauplii explained 48 and $22 \%$ of the variability in feeding success and recent growth during the first-feeding stage, respectively.

\section{Feeding success and recent growth in relation to temperature}

No relationship was found between the feeding success of larval Atlantic mackerel and temperature in any of the length classes considered (Fig. $7 \mathrm{a}-\mathrm{d}$ ). With 
the exception of the 3 to $7 \mathrm{~d}$ age interval (Fig. 7e), a positive linear relationship was observed between detrended recent $3 \mathrm{~d}$ mean growth rate and the average temperature prevailing in the area during the last $3 \mathrm{~d}$ of life (Fig. $7 \mathrm{f}-\mathrm{h}$ ). In these 3 age classes, temperature explained between $29 \%$ (larvae >15 d) and 46\% (larvae 12 to $15 \mathrm{~d}$ ) of the variance observed in growth rate.

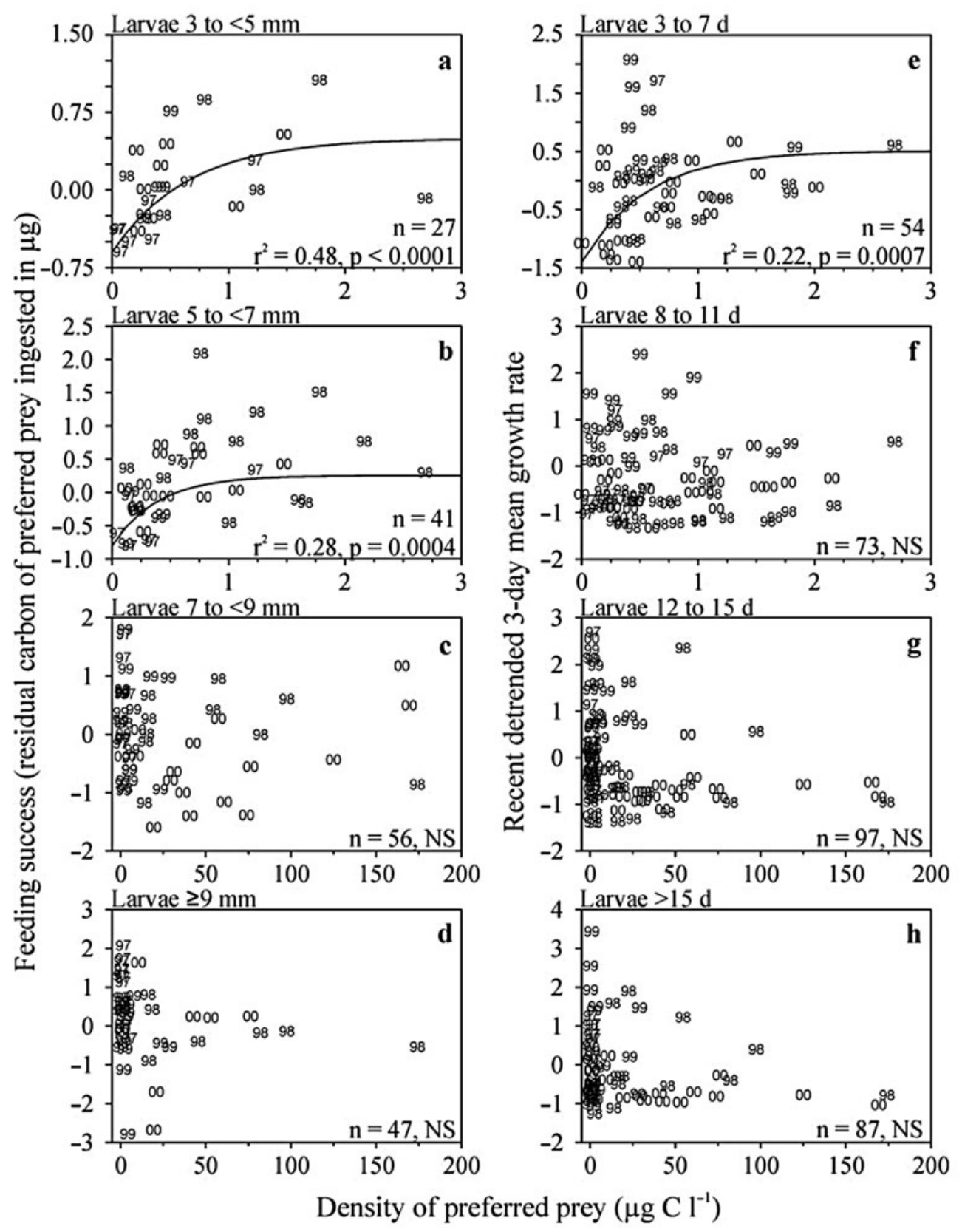

Fig. 6. Scomber scombrus. (a-d) Larval feeding success on preferred prey and (e-h) recent 3 d mean growth rate, related to the density of preferred prey: $(\mathrm{a}, \mathrm{b}, \mathrm{e}, \mathrm{f})$ Pseudocalanus sp. nauplii and $(\mathrm{c}, \mathrm{d}, \mathrm{g}, \mathrm{h})$ cladocerans and fish larvae $<7 \mathrm{~mm}$. Individual feeding success and growth were averaged per net tow and represented by year of sampling. Exponential rise-to-maximum functional relationships $(\mathrm{a}, \mathrm{b}, \mathrm{e})$ were fitted with a statistical weight corresponding to the inverse SD. Equations of the exponential riseto-maximum functions are (a) $y=1.099\left(1-\mathrm{e}^{-0.0015 x}\right)-0.585$; (b) $y=1.053\left(1-\mathrm{e}^{-0.0026 x}\right)-0.801$; (e) $y=1.909\left(1-\mathrm{e}^{-0.0018 x}\right)-1.38$ 
in marine fish (Hjort 1914, Anderson 1988, Cushing 1990, Houde 2008). And yet, few field studies demonstrate that feeding is actually suboptimal at low prey availability (Ellertsen et al. 1989, Fortier et al. 1996, Fortier \& Villeneuve 1996). Moreover, a roughly equal number of field studies provide evidence in support and against a link between growth (or condition) and food (e.g. Baumann et al. 2003, Pepin et al. 2003, Taka- hashi \& Watanabe 2005, Buckley \& Durbin 2006), and when statistically significant, the relationships are often weak (Rilling \& Houde 1999, Takasuka \& Aoki 2006, present study). Much of the ambiguity in the links between prey abundance and vital rates can be traced to (1) the cost of describing with sufficient taxonomical resolution the shifting diet of fish larvae during ontogeny, (2) the difficulty of tracking the actual
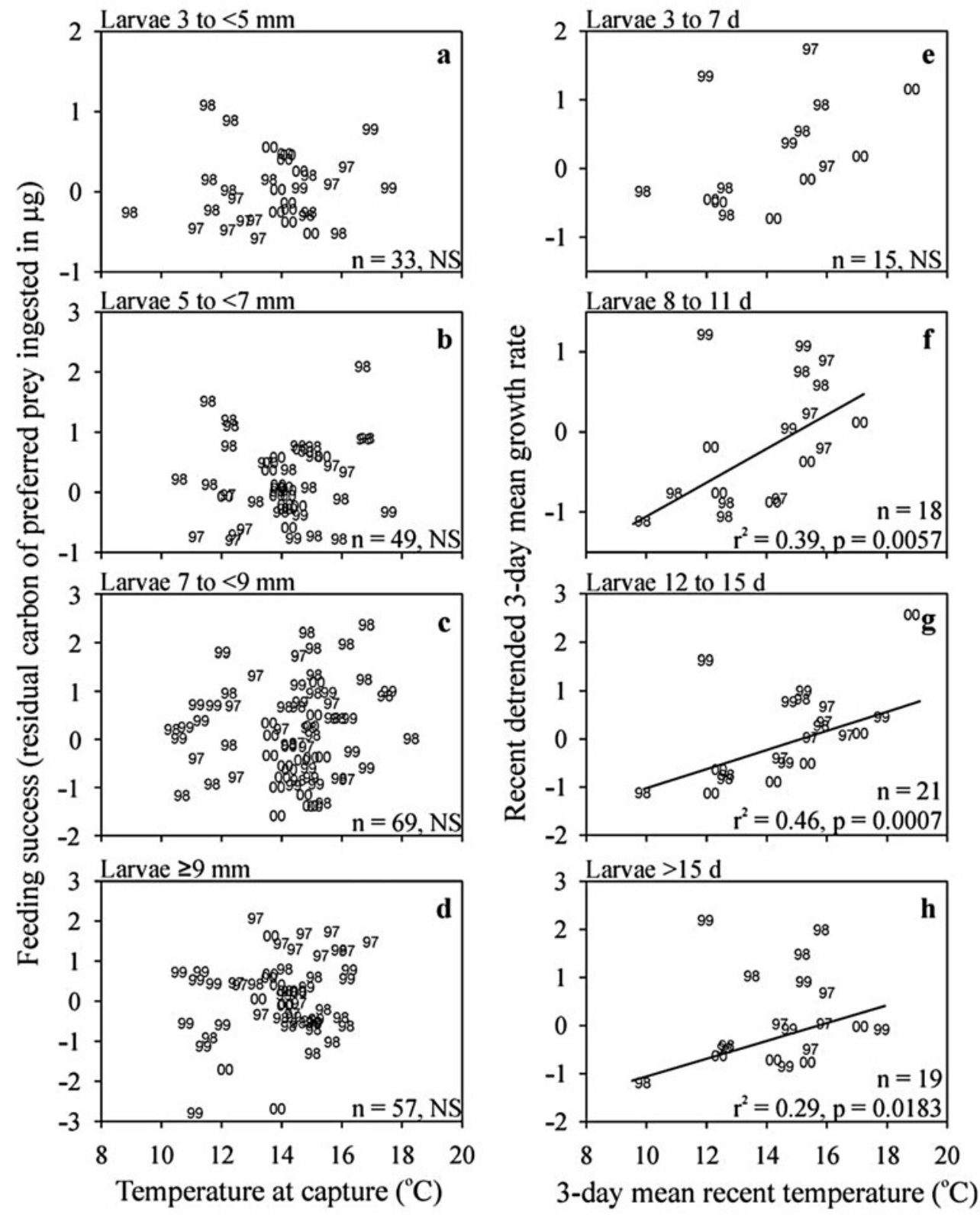

Fig. 7. Scomber scombrus. (a-d) Larval feeding success on preferred prey and (e-h) recent 3 d mean growth rate, related to temperature. Preferred prey are (a,b) Pseudocalanus sp. nauplii and (c,d) cladocerans and fish larvae $<7 \mathrm{~mm}$. Individual feeding success and growth were averaged per net tow and sampling day, respectively, and represented by year of sampling. Linear relationships between growth and temperature $(\mathrm{f}-\mathrm{h})$ were fitted with a statistical weight corresponding to the inverse SD. Equations of the linear regressions are (f) $y=0.211 x-3.168$; (g) $y=0.199 x-3.012$; (h) $y=0.185 x-2.911$ 
availability of these prey during the first weeks of growth in the plankton, (3) the quasi-impossibility of measuring actual food intake (carbon per time unit) in situ, and (4) the confounding effects of other determinants of feeding and growth such as turbulence, temperature, light, and photoperiod. In a notable exception, Buckley \& Durbin (2006) reported a strong $\left(r^{2} \geq 0.8\right)$ relationship of the expected exponential riseto-maximum type between the growth of Atlantic cod Gadus morhua and haddock Melanogrammus aeglefinus larvae and the availability of their preferred prey Pseudocalanus spp. on Georges Bank in spring. Interestingly, including other copepod prey in the analysis blurred the strong functional relationship linking growth to Pseudocalanus spp. This result, revealed by the combination of fine taxonomical specification of prey field and sampling under a wide prey availability spectrum (5 yr of data), suggests that the availability of the most profitable prey dictates growth and supports Hjort's (1914) intuition that not only the abundance but also the suitability of prey are important determinants of successful first feeding and early survival.

In the present study, no statistically significant relationship was found between feeding success or growth of a given larval size class and the summed availability of all its prey in the environment, over the wide range of prey densities recorded during 4 summer seasons. Consistent with Buckley \& Durbin (2006), the expected exponential rise-to-maximum response of feeding success and growth to prey availability was detected in small, first-feeding larvae $(<7 \mathrm{~mm})$ when only the preferred prey Pseudocalanus spp. nauplii was considered in the analysis. Of course, suboptimal intake of the preferred prey does not necessarily imply that energy needs are not fulfilled, since the capture of alternative prey can supply the missing energy. However, the observed dependence of growth on preferred prey density indicates that suboptimal density of the preferred prey actually limited the energy allocated to growth (see also Buckley \& Durbin 2006). This is consistent with the notion that a negatively selected prey of the same energy value as the preferred prey nevertheless provides a lower energy gain due to the higher cost of search and/or capture (Hunter 1980).

\section{Ontogenetic changes in sensitivity to low prey availability}

While the feeding success and growth of mackerel larvae $<7 \mathrm{~mm}$ was limited at low concentration of Pseudocalanus spp. nauplii, no food limitation was detected in the larger larvae that selected cladocerans and fish larvae. This is at odds with observations on the Scotian Shelf where the feeding of mackerel larvae
$<7 \mathrm{~mm}$ was not limited by the availability of copepod nauplii, whereas the incidence of piscivory in larvae of all sizes was limited at concentrations of fish larvae $<0.1 \mathrm{~m}^{-3}$ (Fortier \& Villeneuve 1996). We suspect that the lack of relationship for larvae $<7 \mathrm{~mm}$ on the Scotian Shelf may be linked to the low taxonomical resolution in the identification of copepod nauplii. As for piscivory, the concentration of small fish larvae was in general 2 orders of magnitude higher on the Magdalen Shallows $\left(160 \pm 350 \mathrm{~m}^{-3}\right)$ than on the Scotian Shelf $(0$ to $1.6 \mathrm{~m}^{-3}$ ), which may explain that, in the present study, mackerel larvae were never limited by the abundance of their fish prey. Together, the 2 studies indicate that food limitation in mackerel larvae can occur either during first feeding on copepod nauplii or after the shift to piscivory.

The limitation of feeding success and growth by prey availability quickly decreased with the size of mackerel larvae and no effect was detected beyond a length of $7 \mathrm{~mm}$. This is consistent with numerous reports that suboptimal feeding (e.g. Ellertsen et al. 1989, Fortier \& Villeneuve 1996, Fortier et al. 1996, Conway et al. 1998) and growth (Shoji \& Tanaka 2004, 2006, Buckley \& Durbin 2006) at low prey density concern essentially small larvae at or soon after the initiation of exogenous feeding. All the evidence points to food limitation being important mostly at first feeding when swimming and foraging abilities are low, and that surviving fish larvae quickly acquire the predatory skills needed to avoid suboptimal feeding at low prey supply.

\section{Temperature and growth}

Temperature is often considered the most important environmental factor affecting the vital rates of young fish (e.g. Houde \& Zastrow 1993, Jobling 1997). Several field studies report a strong effect of temperature on gut content (e.g. Michaud et al. 1996, Dower et al. 2002), growth (e.g. Buckley et al. 2004, Baumann et al. 2006, Takasuka et al. 2007) and, ultimately, year-class strength (Ottersen \& Loeng 2000, Takasuka et al. 2007). Buckley et al. (2006) however pointed out the risks of attributing to temperature a portion of the growth variability actually caused by the parallel seasonal variations of photoperiod (light availability). In the present study, the possibility of a confounding effect was unlikely as the seasonal temperature increase corresponded to the reduction of the photoperiod in all years. We observed a positive effect of temperature on growth in mackerel larvae $\geq 8 \mathrm{~d}$ old but not on feeding success. This indicates that the increased food intake necessary to fuel accelerated growth at higher temperature was not detected. The possibility that our index of feeding success based on gut content 
at capture could not detect the parallel increase in ingestion and egestion expected as temperature increases likely explains this paradox.

Bioenergetics models indicate that growth should be a dome-shaped function of temperature if the optimal temperature of the species is exceeded (e.g. Jobling 1997), a prediction supported by recent studies of early growth in demersal and pelagic fish (Baumann et al. 2003, Buckley et al. 2004, Takasuka \& Aoki 2006, Takasuka et al. 2007). On the Magdalen Shallows, the recent growth of mackerel larvae increased linearly over the 10 to $18^{\circ} \mathrm{C}$ range of temperature experienced by the larvae during the $4 \mathrm{yr}$ studied, with no sign of declining growth at the highest temperatures. This suggests an optimal temperature well above $18^{\circ} \mathrm{C}$ and that, in a context of climate change, mackerel larvae could probably resist a significant additional warming of the surface layer in the southern Gulf of St. Lawrence.

\section{Environmental conditions and recruitment variability}

Castonguay et al. (2008) recently reported a strong positive correlation between Atlantic mackerel recruitment and the production of preferred prey (identified in the different spawning grounds) at first feeding over a 20 yr time series in the southern Gulf of St. Lawrence. That result strongly supports our working hypothesis that reduced availability of preferred prey during the larval stage leads to poor recruitment through suboptimal feeding and growth. Our data further suggest that the negative impacts on survival of this early trophic bottleneck are amplified when low temperature prevails during the larval growth season. The weakest year class considered in the present study (1997) was produced during an unusually cold summer in the southern Gulf of St. Lawrence, while the strong recruitment event in 1999 corresponded to an exceptionally warm year. Several studies have highlighted the positive effect of increased temperature on the recruitment of the northernmost populations of Atlantic cod Gadus morhua (Planque \& Frédou 1999, Ottersen \& Loeng 2000). The stock of Atlantic mackerel of the southern Gulf of St. Lawrence also occupies the northern part of the species range in the Northwest Atlantic, and the unusually warm conditions prevailing in the Northwest Atlantic in 1999 may have contributed to the exceptional recruitment in that year. Another well-documented case of record recruitment in 1999 is that of haddock on the Eastern Scotian Shelf, which was attributed to an optimal match between larval emergence and high abundance of adequate prey (Platt et al. 2003, Head et al. 2005). Given that prey supply often limits larval growth in haddock (Buckley et al. 2004), the combination of high prey availability (Platt et al. 2003, Head et al. 2005) and unusually high spring/summer temperature (DFO 2000) could have enhanced larval growth on the Scotian Shelf in 1999 and contributed to the exceptionally high survival of haddock larvae in that year.

In Atlantic mackerel from the southern Gulf of St. Lawrence, the exact mechanism by which temperature impacts recruitment remains unclear. Due to a late emergence in 1997 (Robert et al. 2008), the newly hatched larvae benefited from relatively warm temperatures, at least on the Magdalen Shallows. Also, growth rates in 1999 often exceeded the levels predicted by the multi-year regressions linking growth to prey density and temperature, suggesting that one or more additional variables may have acted in synergy with preferred prey density and temperature to drive exceptional growth in that year. Even if additional factors account for larval growth variability, optimal prey availability and temperature conditions during the larval stage would remain essential for the development of a strong year class.

Acknowledgements. This work is a joint contribution to the programs of Québec-Océan (Université Laval) and the Institut Maurice-Lamontagne (Department of Fisheries and Oceans Canada). Support from the Natural Science and Engineering Research Council of Canada (NSERC) and the NSERC Research Network GLOBEC-Canada to L.F. is acknowledged. We thank K. Levesque, A.-M. Leckman, P. Lafrance, L. Michaud, L. Létourneau, V. Perron, V. Gagné, M. Pilote and H. Cloutier for their contribution to the field work and laboratory analyses. D.R. received scholarships from NSERC, the Fonds Québécois de la Recherche sur la Nature et les Technologies (FQRNT) and Québec-Océan. The comments of 4 anonymous reviewers improved an earlier version of the manuscript. This study is dedicated to the late Anne-Marie Leckman, our collaborator and friend.

\section{LITERATURE CITED}

Anderson JT (1988) A review of size dependent survival during pre-recruit stages of fishes in relation to recruitment. J Northwest Atl Fish Sci 8:55-66

Baumann H, Pepin P, Davidson FJ, Mowbray F, Schnack D, Dower JF (2003) Reconstruction of environmental histories to investigate patterns of larval radiated shanny (Ulvaria subbifurcata) growth and selective survival in a large bay of Newfoundland. ICES J Mar Sci 60:243-258

Baumann H, Hinrichsen HH, Voss R, Stepputtis D, Grygiel W, Clausen LW, Temming A (2006) Linking growth to environmental histories in central Baltic young-of-the-year sprat, Sprattus sprattus: an approach based on otolith microstructure analysis and hydrodynamic modelling. Fish Oceanogr 15:465-476

Bradford MJ (1992) Precision of recruitment predictions from early life stages of marine fishes. Fish Bull US 90:439-453

Buckley LJ, Durbin EG (2006) Seasonal and inter-annual trends in the zooplankton prey and growth rate of 
Atlantic cod (Gadus morhua) and haddock (Melanogrammus aeglefinus) larvae on Georges Bank. Deep-Sea Res II 53:2758-2770

Buckley LJ, Caldarone EM, Lough RG (2004) Optimum temperature and food-limited growth of larval Atlantic cod (Gadus morhua) and haddock (Melanogrammus aeglefinus) on Georges Bank. Fish Oceanogr 13:134-140

Buckley LJ, Caldarone EM, Lough RG, St. Onge-Burns JM (2006) Ontogenetic and seasonal trends in recent growth rates of Atlantic cod and haddock larvae on Georges Bank: effects of photoperiod and temperature. Mar Ecol Prog Ser 325:205-226

Castonguay M, Plourde S, Robert D, Runge JA, Fortier L (2008) Copepod production drives recruitment in a marine fish. Can J Fish Aquat Sci 65:1528-1531

> Chambers RC, Leggett WC (1987) Size and age at metamorphosis in marine fishes: an analysis of laboratory-reared winter flounder (Pseudopleuronectes americanus) with a review of variation in other species. Can J Fish Aquat Sci 44:1936-1947

Chesson J (1978) Measuring preference in selective predation. Ecology 59:211-215

$>$ Conway DVP, Coombs SH, Smith C (1998) Feeding of anchovy Engraulis encrasicolus larvae in the northwestern Adriatic Sea in response to changing hydrobiological conditions. Mar Ecol Prog Ser 175:35-49

Cushing DH (1990) Plankton production and year-class strength in fish populations: an update of the match/ mismatch hypothesis. Adv Mar Biol 26:249-294

de Lafontaine Y, Demers S, Runge JA (1991) Pelagic food web interactions and productivity in the Gulf of St. Lawrence: a perspective. In: Therriault JC (ed) The Gulf of St Lawrence: small ocean or big estuary? Can Spec Publ Fish Aquat Sci 113:99-113

DFO (Department of Fisheries and Oceans Canada) (2000) 1999 state of the ocean: physical oceanographic conditions on the Scotian Shelf, Bay of Fundy and Gulf of Maine. DFO science stock status report G3-01. DFO, Ottawa, ON

> Dower JF, Miller TJ, Leggett WC (1997) The role of microscale turbulence in the feeding ecology of larval fish. Adv Mar Biol 31:169-220

Dower JF, Pepin P, Leggett WC (2002) Using patch studies to link mesoscale patterns of feeding and growth in larval fish to environmental variability. Fish Oceanogr 11: 219-232

Ellertsen B, Fossum P, Solemdal P, Sundby S (1989) Relation between temperature and survival of eggs and first-feeding larvae of northeast Arctic cod (Gadus morhua L.). Rapp P-V Réun Cons Int Explor Mer 191:209-219

Fortier L, Villeneuve A (1996) Cannibalism and predation on fish larvae by larvae of Atlantic mackerel, Scomber scombrus: trophodynamics and potential impact on recruitment. Fish Bull US 94:268-281

Fortier L, Gilbert M, Ponton D, Ingram RG, Robineau B, Legendre L (1996) Impact of freshwater on a subarctic coastal ecosystem under seasonal sea ice (southeastern Hudson Bay, Canada). III. Feeding success of marine fish larvae. J Mar Syst 7:251-265

Head EJH, Brickman D, Harris LR (2005) An exceptional haddock year class and unusual environmental conditions on the Scotian Shelf in 1999. J Plankton Res 27:597-602

Hjort J (1914) Fluctuations in the great fisheries of northern Europe viewed in light of biological research. Rapp P-V Réun Cons Int Explor Mer 20:1-228

Houde ED (1987) Fish early life dynamics and recruitment variability. Am Fish Soc Symp 2:17-29

Houde ED (2008) Emerging from Hjort's shadow. J Northwest
Atl Fish Sci 41:53-70

Houde ED, Schekter RC (1980) Feeding by marine fish larvae: developmental and functional responses. Environ Biol Fishes 5:315-334

Houde ED, Zastrow CE (1993) Ecosystem- and taxon-specific dynamic and energetics properties of larval fish assemblages. Bull Mar Sci 53:290-335

Hunter JR (1980) The feeding behavior and ecology of marine fish larvae. In: Bardach JE, Magnuson JJ, May RC, Reinhart JM (eds) Fish behavior and its use in the capture and culture of fishes. ICLARM Conf Proc 5, Manila, p 287-330

Ivlev VS (1961) Experimental ecology of the feeding of fishes. Yale University Press, New Haven, CT

Jobling M (1997) Temperature and growth: modulation of growth rate via temperature change. In: Wood CM, McDonald DG (eds) Global warming: implications for freshwater and marine fish, Vol 61. Cambridge University Press, Cambridge, p 225-253

Llopiz JK, Cowen RK (2008) Precocious, selective and successful feeding of larval billfishes in the oceanic Straits of Florida. Mar Ecol Prog Ser 358:231-244

> Lough RD, Mountain DG (1996) Effect of small-scale turbulence on feeding rates of larval cod and haddock in stratified water on Georges Bank. Deep-Sea Res II 43: 1745-1772

Michaud J, Fortier L, Rowe P, Ramseier R (1996) Feeding success and survivorship of Arctic cod larvae, Boreogadus saida, in the Northeast Water Polynya (Greenland Sea). Fish Oceanogr 5:120-135

Migoya MC (1989) Étude de la croissance des larves de maquereau bleu (Scomber scombrus) dans le golfe du Saint-Laurent, à partir de l'examen de la microstructure des otolithes. MSc thesis, Université du Québec à Rimouski

Miller TJ, Crowder LB, Rice JA, Marschall EA (1988) Larval size and recruitment mechanisms in fishes: toward a conceptual framework. Can J Fish Aquat Sci 45:1657-1670

Ottersen G, Loeng H (2000) Covariability in early growth and year-class strength of Barents Sea cod, haddock, and herring: the environmental link. ICES J Mar Sci 57:339-348

$>$ Pepin P, Dower JF, Davidson FJM (2003) A spatially explicit study of prey-predator interactions in larval fish: assessing the influence of food and predator abundance on larval growth and survival. Fish Oceanogr 12:19-33

$>$ Planque B, Frédou T (1999) Temperature and the recruitment of Atlantic cod (Gadus morhua). Can J Fish Aquat Sci 56: 2069-2077

> Platt T, Fuentes-Yaco C, Frank KT (2003) Spring algal bloom and larval fish survival. Nature 423:398-399

Rilling GC, Houde ED (1999) Regional and temporal variability in growth and mortality of bay anchovy, Anchoa mitchilli, larvae in Chesapeake Bay. Fish Bull US 97: 555-569

Robert D, Castonguay M, Fortier L (2007) Early growth and recruitment in Atlantic mackerel: discriminating the effects of fast growth and selection for fast growth. Mar Ecol Prog Ser 337:209-219

Robert D, Castonguay M, Fortier L (2008) Effects of intra- and inter-annual variability in prey field on the feeding selectivity of larval Atlantic mackerel (Scomber scombrus). J Plankton Res 30:673-688

Shoji J, Tanaka M (2004) Effect of prey concentration on growth of piscivorous Japanese Spanish mackerel Scomberomorus niphonius larvae in the Seto Inland Sea, Japan. J Appl Ichthyol 20:271-275

> Shoji J, Tanaka M (2006) Growth-selective survival in piscivorous larvae of Japanese Spanish mackerel Scombero- 
morus niphonius: early selection and significance of ichthyoplankton prey supply. Mar Ecol Prog Ser 321: 245-254

Takahashi M, Watanabe Y (2005) Effects of temperature and food availability on growth rate during late larval stage of Japanese anchovy (Engraulis japonicus) in the KuroshioOyashio transition region. Fish Oceanogr 14:223-235

Takasuka A, Aoki I (2006) Environmental determinants of growth rates for larval Japanese anchovy Engraulis japon-

Editorial responsibility: Jon Hare,

Narragansett, Rhode Island, USA icus in different waters. Fish Oceanogr 15:139-149

Takasuka A, Aoki I, Mitani I (2003) Evidence of growthselective predation on larval Japanese anchovy Engraulis japonicus in Sagami Bay. Mar Ecol Prog Ser 252: $223-238$

Takasuka A, Oozeki Y, Aoki I (2007) Optimal growth temperature hypothesis: Why do anchovy flourish and sardine collapse or vice versa under the same ocean regime? Can J Fish Aquat Sci 64:768-776

Submitted: April 2, 2008; Accepted: November 16, 2008 Proofs received from author(s): February 6, 2009 